\title{
PEMBELAJARAN PAUD DENGAN STRATEGI OUT DOOR
}

\author{
Susi Herlinda \\ STKIP Aisyiyah Riau Pekanbaru, Indonesia \\ bunda.susi.2@gmail.com
}

\begin{abstract}
ABSTRAK
Strategi belajar OUT DOOR pada pembelajaran PAUD dapat membuat suasana belajar enjoi dan menyenangkan sehingga dapat membuat peserta didik bersemangat untuk belajar. Selain dari pada itu Strategi belajar OUT DOOR juga memperkenalkan alam secara natural dan sangat banyak menfaat yang dirasakan peserta didik, kemudian dengan OUT DOOR akan ada manfaat dalam keseluruhan perkembangan aspek anak seperti aspek fisik, kognitif, bahasa, emosi dan aspek sosial. Strategi OUR DOOR juga dapat membuat anak berekplorasi dan juga tantangan untuk kemampuan motorik kasar dan halus. Strategi belajar OUT DOOR harus memiliki tempat yang luas sehingga anak betul betul tertarik dan menyenangkan sesuai dengan tema tema belajaryang dijelaskan pada anak sehingga anak juga bisa termotivasi anak belajar.
\end{abstract}

Kata kunci: Strategi Belajar Outdoor

\section{PENDAHULUAN}

Semua anak pada PAUD sangat menyukai kegiata belajar dilakukan diluar ruangan (out door) karena kegiatan ini merupakan bagian integral dari pembelajaran pada PAUD, karena merupakan taman bermain alamiah, anak anak bisa berkebun, memelihara binatang, bermain air dan menikmati sejuk serta bersihnya alam ini. Lingkungan belajar OUT DOOR ini juga sebagai tempat anak bisa mengekpresikan keinginanya karena rasa keingin tahuan anak terpancing dengan berada dialam terbuka tersebut.

Penyelenggaraan PAUD harus difahami tujuannya karena ini sangat penting sehingga tujuan tersebut harus bisa tercapai dengan strategi yang bermacam macam. Para ahli yang menekuni PAUD diantaranya Bredecam \& Cople berpendapat bahwa PAUD dirancang untuk melayani dan meningkatkan perkembangan kognitif, sosial, emosional, bahasa, dan fisik anak. Kemudian Bechler \& Snowman mejelaskan tujuan pembelajran Pada PAUD adalah memfasilitasi pertumbuhan dan perkembangan anak secara optimal dan menyeluruh sesuai dengan norma norma dan nilai nilai kehidupan yang dianut. 
Dalam Undang Undang sistim Pendidikan Nasional (UU SISDIKNAS) dinyatakan bahwa tujuan pendidikan PAUD adalah: Pemberian ransangan untuk membantu pertumbuhan dan perkembangan jasmani dan rohani, agar anak memiliki kesiapan dalam memasuki pendidikan lebih lanjut. Rumusan Undang Undang ini diperjelas lagi dalam tujuan kurikulum TK 2004 dengan rincian sebagai berikut: bahawa PAUD bertujuan membantu anak untuk mengembangkan berbagai potensi baik psikis dan fisik yang meliputi moral dan nilai nilai agama, sosial emosional, kognitif, bahasa, fisik motorik, kemandirian dan seni untuk mempersiapkan diri memasuki pendidikan dasar. Kemudian secara rinci kurikulum tadi dijabarkan lagi dalam fungsi penyelenggaraan PAUD untuk lebih mudah memahaminya lagi. Funsi fungsi yang dimaksud adalah: (1) PAUD berfungsi mengenalkan peraturan dan menanamkan disiplin pada anak. (2) PAUD berfungsi mengenalkan anak dengan dunia sekitarnya. (3) PAUD berfungsi menumbuhkan sikap dan prilaku yang baik. (4) PAUD berfungsi mengembangkan kemampuan berkomunikasi dan bersosialisasi, (5) Paud berfungsi mengembangkan ketrampilan, kreativitas, dan kemampuan yang dimiliki oleh anak, (6) PAUD berfungsi menyiapkan anak untuk memasuki pendidikan dasar.

Begitu jelasnya tujuan pendidikan tentu sangat penting untuk diperhatikan terutama pengeloaan lingkungan belajar untuk anak. Perhatian pengolaan lingkungan belajar tersebut betul betul dirancang dengan mengkreasikan alam sebagai tempat belajar.

\section{PEMBAHASAN}

\section{A. Pembelajaran pada PAUD}

Pembelajaran adalah penyiapan suatu kondisi agar terjadinya belajar ( Nana Sudjana , 1987 ). Pembelajran adalah upaya logis yang didasrkan pada kebutuhan kebutuhan belajar anak. Pembelajaran akan sangat bergantung pada pemahamam guru tentang hakikat anak sebagai peserta atau sasaran belajar. Dengan demikian pembelajaran bersifat khusus sesuai dengan karakteristik dan kebutuhan anak yang dilayaninya.

Sebelum dirancang dan terjadinya pembelajaran di PAUD maka kita harus perlu mengetahui bagaimana perkembangan dan cara belajar pada PAUD tersebut. Adapun perkembangan anak usia dini tersebut menurut Piaget, 1952 ; Mustaffa, 2002 bahwa anak anak dengan aktif secara terus menerus mengolah berbagai pengalaman dengan cara mengembangkan dan mereorganisasikan struktur mentalnya melalui berbagai proses yang dilakukan dari waktu ke waktu dalam berbagai kesempatan.

Secara konseptual perkembangan anak dan belajar anak dijelaskan oleh teori Jean Piaget yang selama ini sangat mempengaruhi praktek pendidikan pada PAUD. Menurut teorinya anak anak berkembang secara kognitif melalui keterlibatan aktif dengan lingkungannya, dan setiap tahap perkembangannya saling terjalin dan terintergrasi satu sama lainnya (Mustaffa, 2002). Perkembangan yang dimaksud adalah sebagai berikut: 
1. Tahap usia sensori motor $(0-2$ tahun $)$

2. Tahap berfikir pra - operasional ( $2-7$ tahun $)$

3. Tahap operasi konret $(7-11$ tahun $)$

4. Tahap operasi formal ( $11-15$ tahun katas )

Keempat tahap tersebut sangat besar pengaruhnya terhadap praktek pembelajaran. Setiap tahap perkembangan tersebut haris diperhatikan dan dipahami secara seksama agar dalam pengemabangannya dipembelajaran berjalan sesuai sebagaimana yang diharapkan.

Dengan tahapan tahapan perkembangan diatas maka guru perlu merancang kegitan pembelajaran dengan pola rutin, pembiasaan, serta jangan lupa pembelajran itu juga harus menstimulan serta menyenamgkan bagi mereka.

\section{B. Pengertian Outdoor}

Outdoor adalah suatu kegiatan pembelajaran yang secara lansung dilakukan dialam tebuka dengan memanfaatkan alam sekitarnya sebagai media pembelajaran, kegiatan belajar sambil bermain dengan diisi permainan ketangkasan dalam usaha membentuk kepribadian, memantapkan permasaalahan kepemimpinan untuk membentuk karakter anak dan percaya diri.

Pepen Supandi (2007) mengemukakan ada dua alasan kenapa bermain Outdoor dipakai untuk belajar pada PAUD. Pertama banyak kemampuan anak yang harus dikembangkan. Kedua orang tua yang sibuk selalu memberikan permainan komputer, laptop, atau nonton televisi sehingga menyebabkan anak jauh dari kegiatan bermain.

Bermain Outdoor adalah permainan yang diberikan pada anak usia dini dengan bermain dan belajar mengenalkan alam dan menggunakan bermacam area dialam yang natural sehingga anak dapat mengobservasi benda benda alam yang ada disekitarnya serta akan mendapatkan pengalaman yang unik. Seperti SCIENCE yaitu berekplorasi dan mengobservasi dengan tangannya sendiri. Anak dapat melihat tanaman tumbuh, anak bisa mengikuti perubahan musim, melihat perubahan warna, memegang kulit pohon, mendengar suara jangkrik, mencium udara setelah hujan turun.

Prinsip prinsip penataan area Outdoor yang harus diperhatikan adalah:

1. Memenuhi aturan keamanan

2. Harus sesuai dengan karekteristik alamiah anak

3. Disain Linkungan luar kelas harus didasarkan kebutuhan anak

4. Secara estetis harus menyenangkan

Secara spesifik alat permainan Outdoor harus fleksibel untuk memenuhi kebutuhan dan prasyarat serta memasukkan faktor lokasi, ukuran tanah, permukaan dan suasananya. Ada beberapa alat bermain yang juga harus jadi pertimbangan variasinya seperti aktivitas menggali, menimbun, bermain dengan binatang, berkebun, bertukang kayu. Kunci bisa suksesnya bermain Outdoor adalah jauh dari keramaian dan kebisingan, jauh dari hiruk pikuk lalulintas serta terjaga keamanan anak. 


\section{Tujuan strategi bermain Outdoor}

Tempat yang luas adalah salah satu ciri dari lingkungan Outdoor menjadi baik dan sempurna untuk bermain anak anak sehingga dapat mengembangkan kemampuan otot otot besar, dengan berlari, memanjat. Dengan outdoor dapat meningkatkan ketahanan, keseimbangan dan koordinasi tubuh anak.

Dalam kurikulum TK / Paud lingkungan bermain Outdooradalah hal yang memerlukan perhatian yang sama dengan kegiatan didalam kelas, hal ini berarti berbagai pengembangan aspek dipelajari seperti sosial emosionala, kognitif, dan fisik.

Kemudian pada bermain Outdoor ini pembelajaran guru juga dapat mengembangka dan memananmkan pendidikan karakter antara lain:

a. Guru dapat mengarahkan anak secara kondisional

b. Guru dapat menanamkan pendidikan karakter dengan melakukan pembiasaan disekolah

c. Guru menjadi model keteladanan bagi anak

\section{A. Manfaat strategi belajar Outdoor bagi anak}

Dalam implementasinya strategi Outdoor memiliki pengaruh terhadap tiga perkembangan aspek ana

1. Aspek perkembangan sosial emosional

Dalam prakteknya Outdoor dapat memngembangkan kecerdasan emosional anak sehingga sedini mungkin anak telah dibekali rasa kasih sayang, cinta, rasa dan iba. Dengan cinta anak akan mengenali pikiran, perasaan dan iba kepada orang lain (empathy) dengan cinta anak akan memiliki rasa iba (compasion) dengan cinta membuat anak ramah dan penuh kasih sayang (kidness) cinta mengajari anak bermurah hati (generosity) cinta membuat anak menjadi pemaaf (forgiveness) cinta juga mengkondisikan anak suka membantu orang lain (service). Untuk mewujudkan hal diatas maka perlu diimplementasikan dalam bentuk kegiatan Outdoor sebagai berikut :

a. Demontasi merawat tanaman

b. Berunding dan kompromi sesama teman dalam menggunakan peralatan

c. Mengekpresikan kreativitas dengan membuat berbagai benda seni dari lingkungan alam sekitarnya.

d. Menambahkan kemandirian seperti mendaki, menurun, dengan menggunakan tali sendiri

e. Memperkuat kekuatan fisik motorik halus dan kasar seperti bermain pasir dan berlari.

2. Aspek perkembangan kognitif

Piaget mengatakan " Perkembangan merupakan suatu proses yang bersifat kumulatif artinya perkembangan terdahulu akan menjadi dasar untuk perkembangan selanjutnya.makanya apabila terjadi hambatan pada perkembangan terdahulu maka 
perkembangan selanjutnya juga akan mengalami hambatan. Oleh karena itu sangat diharapkan stimulan bagi anak agar fase fase perkembangan berjalan secara optimal. Kegiatan Outdoor sangat mebantu aktivitas ini, karena dalam implemntasinya anak dapat menangkap secara utuh berbagai pengalaman kognisi secara alami tanpa mengalami tekanan karena dilakukan dalam bermain.

Untuk mewujudkan hal tersebut maka dalam merancang kegita Outdoor yang terkait dengan perkembangan kognitif dilakukan dalam bentuk:

a. Anak diarahkan untuk bisa membuat keputusan sendiri

b. Anak diarahkan untuk mempunyai ide dalam segala bentuk permainan yang diberikan

c. Memecahkan masaalah dari setiap permainan yang diberikan seperti membuat terowong dipasir dan lainnya

d. Menggali pengalaman dari permaianan berbagai peeran

e. Dapat bekerjasama dengan teman sepermainannya

f. Memperkaya kosa katadalam berdialog dengan tamannya

3. Aspek perkembangan fisik

Pada anak usia dini sangat diharapkan memiliki perkembangan fisik yang bagus, karena akan mendorong bangkitnya kognisi anak bahkan akan bermuara pada kecerdasan anak. Strategi Outdoor memberikan ruang gerak bebas, dan secara bersamaan dapat meningkatkan perkembangan anak secara total dan optimal. Untuk mewujudkan hal tersebut perlu dirancang kegiatan Outdoor yang terkait dengan perkembangan fisik seperti:

a. Mengembangkan motorik kasar dalam setiap kegiatan bermain, berlari, mendaki, bergelayut, melompat, meloncat tali.

b. Mengembangkan motorik halus dalam kegiatan bermain seperti bermain air, pasir, menggambar dipasir, melukis, mengumpulkan benda benda kecil,

c. Melakukan kegiatan koordinasi dengan mata dan tangan

d. Mengatur keseimbangan badan dalam melakukan kegiatan permainan

e. Menunjukkan ketekunan dan ketahanan dalam melakukan kegiatan bermain dari.

4. Perkembangan aspek moral dan agama anak

a. Anak dapat diajak bermain dengan bercerita gambar dimana gambar menunjukan untuk hidup dengan tertib seperti melatih teratur tentang makan, minum dan tidur sambil berkomunikasi dengan anak dengan menunjukan gambar cerita tersebut.

b. Membuat pertanyaan sedehana kepada anak tentang gambar orang yang malakukan ibadah.

c. Memperagakan lansung tentang sifat pemahaman anak tentang nilai nilai moral dan agama dan anak mengikuti.b 
B. Spesifikasi Lingkungan belajar Outdoor

a. Lokasi

Untuk lokasi memang harus diperhatikan termasuk kodusifnya tempat sehingga proses pembelajaran dapat berjalan dengan nyaman, tenang, dan mencerdaskan. Kemudian harus ada jalur tranportasi sehingga orang mudah mengakses anaknya.

b. Ukuran

Sangat penting ukuran luas tempat anak bermain karena anak bermain berlari kemana mana dengan tidak menghiraukan tabrakan dengan temannya, makanya perlu disediakan lahan yang luas supaya anak bermain dengan nyaman dan betah.

c. Luas tanah dan pagar

Pada prinsipnya rasionalisasi perbandingan antara luas tanah, luas bangunan, dan daya tampung anak didik yang diterima. Luas tanah berkaitan dengan berkenaan dengan penyediaan lahan bermain diarea terbuka b3esrta kelengkapan sarana dan prasarana sedangkan luas bangunan berkaitan dengan kapasitas jumlah anak yang ditampung.

Dalam konteks PAUD keberadaan ruang terbuka merupakan suatu keniscayaan sebab ruang terbuka akan menjadi ajang kreativitas tanpa batas untuk anak anak.

Kemudian semua lahan Outdoor harus dipagar agar anak anak dipastikan aman untuk bermain dan terhindar dari hal hal yang membahayakan anak.

\section{PENUTUP}

\section{A. Kesimpulan}

Strategi Outdoo dalam bembelajaran PAUD sangat bermanfaat terutama dari aspek aspek perkembangan anak seperti:

1. Fisik.

Dengan banyak anak bergerak dialam terbuka dimana ini mempunyai tujuan dasar dari segala keseimbangan tubuh dan pikiran anak. Anak juga bergerak dengan lincah yang merupakan generelisasi untuk kelincahan perfikir, banyak bergerak membuat anak sehat. 
2. Kognitif.

Dengan bermain dialam terbuka membuat anak lebih luas wawasannya. Bermacam wawasan yang didapat anak seperti wawasan lingkungan, dan wawasan macam macam permaianan sehingga muncul kreativitas anak dalam memecahkan masaalah. kesemauanya berkaitan dengan kemampuan anak mengingat.

3. Emosi.

Dengan bermain anak akan mengalami bermacam macam ragam emosi (senang, sedih, marah, malu dan bersalah). Ketika bermain dialam dan banyak melakukan gerakan akan mengurangi emosinya.

4. Sosial.

Bermain dialam terbuka bersama sama dengan teman teman sangat banyak menstimulan perasaan sosial, karena bermain bersama banyak melakukan kerjasama yang saling membantu, saling meolak dan lainya.

5. Bahasa

Dengan bermain anak mendapatkan kosakata tentang kehidupan diluar ruang ketika berinteraksi dengan taman teman, dan juga sambil belajar cara berkomunikasi dengan teman.

\section{DAFTAR PUSTAKA}

Andang, Ismail. (2006). Education Games, Menjadi cerdas dan ceria dengan Permainan Edukatif. Penerbit Pilar Media. Jakarta.

Anggani Sudono, (2006 ), Sumber Belajar dan Alat Permainan Untuk Pendidikan Usia Dini. Jakarta : Grasindo

Arikunto, Suharsimi, ( 1992 ), Pengelolaan Kelas dan Siswa Sebuah Pendekatan Evaluatif. Kakarta: Rajawali

Carrol Ja, ( 1991 ), Centers For Early Learners Throughout the Year.

Cucu Eliyawati, (2005), Pemilihan dan Pengembangan Sumber Balajar untuk Anak Usia Dini, jakarta: depdiknas. Dirjen dikti.

Direktorat PAUD, Dijen PLS ( 2006 ). Pedoman teknis penyelenggaraan TPA. Jakarta: Depdiknas. 
Ibrahim, R \& Syaodih. ( 2003 ). Perencanaan Pengajaran. Jakarta: Rieneka.

Mariyana, Rita, dkk, ( 2010 ) Strategi pengelolaan Lingkungan belajar. Jakarta: departemen Pendidikan Nasional direktorat Jendral Pendidikan Tinggi.

Pepen Supendi Dkk ( 2007 ). Permainan Games yang menyenangkan di Indoor dan Outdoor, penerbit Swadaya Jakarta. 